\title{
Laboratory Evaluation of Botanical Effect on Yam Tuber Beetle (Heteroligus Meles Billberger) (Coleoptera: Dynastidae) Damage and Weight Loss in White Yam (Dioscorea Rotundata Poir)
}

\author{
Okoroafor, $\mathrm{E}^{1}$, I. Onu ${ }^{2}$, C. I. Amatobi \\ ${ }^{I}$ Biotechnology and Farm Health Unit, Institute Of Food Security, Department of Crop and Environmental \\ Protection, University of Agriculture Makurdi P.M.B 2373, Nigeria \\ ${ }^{2}$ Department of Crop Protection, Faculty of Agriculture, Institute for Agricultural Research, Ahmadu Bello \\ University, Zaria, P.M.B 1044, Samaru Zaria, Nigeria.
}

\begin{abstract}
The deterrent effect of powdered husk of Parkia biglobosa (Jacq), seed and leaf of Azadirachta. indica (Juss) on severity of feeding by Heteroligus meles (Billb) in yam was evaluated in the laboratory under ambient condition (temp: $24-29^{\circ} \mathrm{C}$ and $73-76 \% \mathrm{RH}$ ). Each powder were tested at the rate of $0.84 \mathrm{~g} / 210 \mathrm{~g}$ of yam sett from $50 \%$ dust formulation and $2.5 \mathrm{~g} / 500 \mathrm{~g}$ of soil in plastic cages against the beetle along with untreated control which were replicated three times and arranged in completely randomized design (CRD).This study revealed progressive increase in Damage and weight loss over time. Damage reduced in treated tubers in cages and Weight loss rated low for treated tubers with A.indica leave and seed powder (3-8\%)and,6-22\% for Parkia husk treatment compared with 27-49\% for the untreated tubers within 2-8 weeks respectively.
\end{abstract}

Key words: Laboratory, Evaluation, Effect, Plant Extracts, Damage, Weight Loss, Control, Heteroligus meles, Dioscorea rotundata.

\section{Introduction}

Yam beetle, Heteroligus meles is a serious soil insect pest of yam in riverine areas particularly in the forest zones, up to the savanna region along the Benue-Niger. One major constraint to yam production is the damage caused on yam tubers by the beetle in the forest and Guinea savanna zones of Nigeria(Onwueme, 1978, Tobih et al.,2007a;Okoroafor et al., 2007,2009). The beetle feed and creates spherical and semi-spherical lesions of varying sizes on tubers in the range of 1 to 20 holes in a tuber(Taylor,1964;Tobih et al,2007a;Okoroafor et al.,2009). Adult $\mathrm{H}$. meles feeds on yam tuber creating large semi spherical holes of $1-2.5 \mathrm{~cm}$ Taylor(1964) which predisposes tubers to fungal and bacterial attacks on the field and during storage (Morse et.al.,2000).The feeding of H.meles cause about 22-77 \% tuber loss, drastic reduction of yield and market value, and damage in extreme cases resulting from adult feeding on yam can cause plant death (Taylor, 1964). It is important to control this beetle on yams since yams are significant sources of calories, calcium, iron, thiamine and ascorbic acid (Vitamin C) (Coursey, 1967). It is a staple food for millions of people in tropical countries, notably in West Africa, the Caribbean's and parts of southeast Nigeria (Hahn et al., 1987)..

The use of organochlorine insecticide such as Aldrin $2.5 \%$ dust proved effective and economical in controlling the beetle (Taylor, 1967), and was widely used by farmers in Nigeria. However, Aldrin dust was banned by Nigeria government due to undesirable side effects such as tumor promotion, carcinogenicity, neurotoxicity in human and animals coupled with its persistence and residue problems in the soil, thus leaving farmers handicapped. Some synthetic insecticides found effective as alternative poses problem of handling by rural farmers, high cost, human toxicity, environmental hazard, pest resistance.Such insecticides reported were Carbofuran (Emehute et al, 1991, Umeozor, 1998), Chlorpyriphos(Tricel 48 EC) and endosulfan (endocel 35EC) (Tobih et al., 2007b). Thus this study investigated the potency of Parkia biglobosa husk,,and,,A indica leaf and seed extracts for controlling the voracious feeding by H. meles on yam tubers.

\section{Materials And Method}

The experiment was conducted at the Crop Science laboratory, University of Agriculture Makurdi, Benue state, Nigeria to investigate the effect of Parkia biglobosa husk, A indica seed and leaf extract on feeding of $\mathrm{H}$. meles on yam tubers. The dust formulation weighing $1.67 \mathrm{~g}$ contained $0.84 \mathrm{~g}$ of each plant extract was weighed on a Metler balance (model 2000) and was poured into the Petri dishes where $3 \mathrm{mls}$ of clean water was added and stirred to form slurry. The bioactivity test was conducted with the aqueous slurry of A.indica seed and leaf, and Parkia biglobosa husk extract on the tuber setts, and 500g soil treated with $25 \%$ solution of each plant extract and exposed to three beetles per cage. The slurry were applied topically on the yam sett . Yam setts weighing $210 \mathrm{~g}$ with disc surface diameter of $9 \mathrm{~cm}$ and height of $4.5 \mathrm{~cm}$ were used. Cages were assigned to each treatment and were arranged in a Completely Randomized Design (CRD) and replicated three 
times respectively. The cages were kept on the laboratory bench for observation under ambient temperature of $24^{\circ} \mathrm{c} \pm 5$ and relative humidity of $73 \% . \pm 3 \%$. Damage caused on yam setts was observed from $24 \mathrm{hrs}$ and the experiment was terminated at the end of eight weeks of beetle exposure to treated and untreated yams. Parameters recorded were number of holes, depth and diameter of feeding holes. The weight loss of tuber after feeding by the beetle was determined.

Weight loss $(\%)=$ Initial $\mathrm{wt}-$ final $\mathrm{wt} \quad \mathrm{x} 100$

Initial wt

From the weight loss data, five scale of rating was defined, where $1=1-10 \%$ tuber wt loss, $2=11-20 \%$ wt loss, $3=21-30 \%$ wt loss, $4=31-40 \%$ wt loss, and $5=41-50 \%$ wt loss.

\section{Acquisition of Heteroligus meles Billb:}

Adult H. meles were collected in perforated containers with wet soil sample from farmers' field in August . Adult H. meles were sourced from yam farms belonging to farmers in the experimental area. The beetle is presented in Plate 1. The beetles were identified and confirmed as $\mathrm{H}$. meles using the reference materials in the Insect Museum, Department of Crop Protection, Ahmadu Bello University, Zaria.

\section{Plant material preparation and treatment:}

Mature green neem leaves were plucked from the tree and seeds were picked from under the neem trees (Azadirachta indica, A. Juss). The neem leaves and seeds were air dried under ambient air for three days in the month of March when radiation was $13.5 \mathrm{cal} \mathrm{cm}^{2}$ day $^{1}$. The husk from pods of Parkia biglobosa Jacq was sourced from the month of February to May. The husk was sun dried for five days while the neem leaves and seeds were air dried and separately pounded into powder using pestle and mortar. The powder was sieved with $0.50 \mathrm{~mm}$ pore size sieve and packed in respective polythene bags and stored until use. Fifty percent of the plant powders were formulated with the organic ash respectively and used as the treatments. The ash was used in the mixture to spread the active materials on the tubers.

\section{Description of plastic cage for Heteroligus meles}

The cage was made up of a perforated plastic strainer and sieve made of plastic with fine pore mesh for entrance of air. The sieve made of plastic has $22 \mathrm{~cm}$ surface diameter and $6.5 \mathrm{~cm}$ height which was inverted in the perforated plastic strainer with surface diameter of $24 \mathrm{~cm}$ and height of $10 \mathrm{~cm}$ (Plate 1). The top of the cage was wedged with about $200 \mathrm{~g}$ object to prevent the forceful flight of H.meles in the night.

\section{Statistical Analysis}

Data obtained on number, depth and diameter of feeding holes created by H.meles on tubers and tuber weight reduction expressed in percentage weight loss were analyzed using analysis of variance (ANOVA) for a CRD considering time as a factor for determining severity of damage.. SAS software version 8(2) (SAS 2000) was used at the IAR data processing unit, Ahmadu Bello University Zaria,Nigeria.The means were separated using Student Newman Keuls test (SNK test at 5\% level of significance)

\section{Results and Discussion}

The severity of feeding at 8 weeks caused the number of feeding holes to decrease when holes coalesced in untreated tubers and the depth of feeding holes on untreated tubers was significantly $(\mathrm{P}<0.05)$ high at 2 weeks compared with negligible depth for the treated tubers with botanicals (Figs 1 and 2 ).The results showed progressive increase in damage and weight loss over time.The diameter of the feeding holes increase on the untreated tuber at 8 weeks leading to coalesced holes indicating severe feeding that reduce market value by the beetles ( Fig 3 ). Eight weeks after beetle exposure to feeding,weight loss of $8 \%$ and $22 \%$ were recorded respectively for tubers treated with A.indica and P. biglobosa husk extracts and were significantly lower $(\mathrm{P}<0.05)$ compared with the untreated tubers that recorded $49 \%$ weight loss (Table 1$)$. Weight loss for all the treated tubers at 2-8 weeks feeding by the beetle ranged from $3-9.5 \%$ on scale 1 rating with exceptional case of Parkia treatment compared with $27-49 \%$ weight loss in untreated tubers on scaie 4 and 5 signifying high and very high weight loss within 2-8 weeks of feeding..

Application of Parkia biglobosa husk extract, A. indica seed and leaf extract at the rate of $0.84 \mathrm{~g} / 210 \mathrm{~g}$ on yam sett and $2.5 \mathrm{~g} / 500 \mathrm{~g}$ soil per cage showed high potency in the control of $\mathrm{H}$. meles in the laboratory.

The efficacy of Parkia husk powder in reduction of feeding damage by H.meles in this study might be due to the presence of phytotoxins in Parkia husk which must have contributed to its bioactivities on $\mathrm{H}$. meles in the laboratory.The bioactivity in Parkia husk was reported by Thacker (2002);Sabiiti and cobbina (1992).

The efficacy of A. indica seed in this study might be due to the presence of active components such as Azadirachtin A, 26-epoxynimbin, 6-acetylacetate, sodium nimbidate while that of A. indica leaf might be 
attributed to the presence of bioactive components such as Vilasinin from green leaves, 6-Acetylnimbandiol, 6Acetyl-niminene reported to be present in the leaf and can be utilize as pesticide (Gopinathan, 2007).

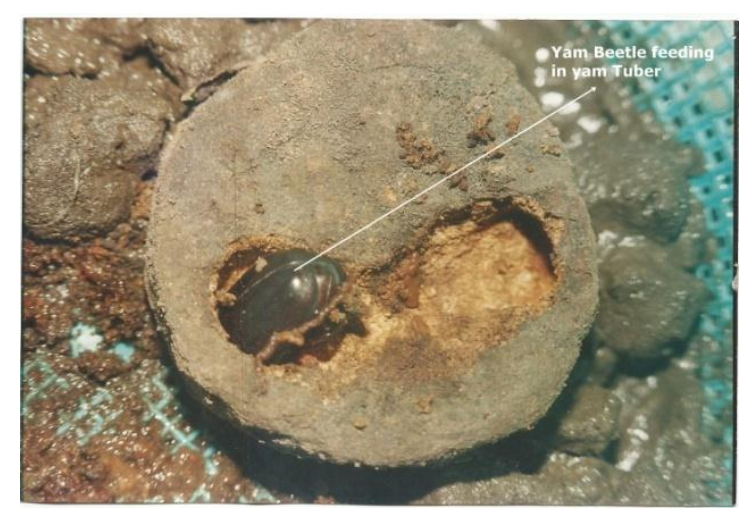

Plate 1: Yam beetle feeding in untreated yam tuber.

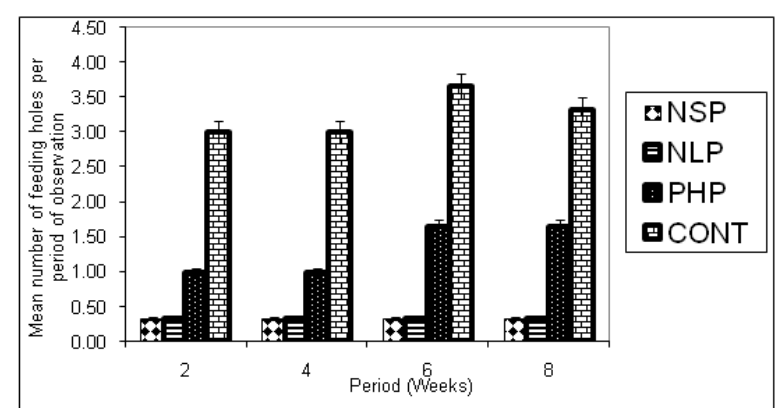

Figure 1: Effect of Parkia husk and Neem extracts on feeding holes created by Heteroligus meles (yam beetle) in yam tuber within eight weeks of infestation..

$\mathrm{NSP}=$ Neem seed powder, NLP $=$ Neem leaf powder, $\mathrm{PHP}=$ Parkia husk powder Cont $=$ Control.

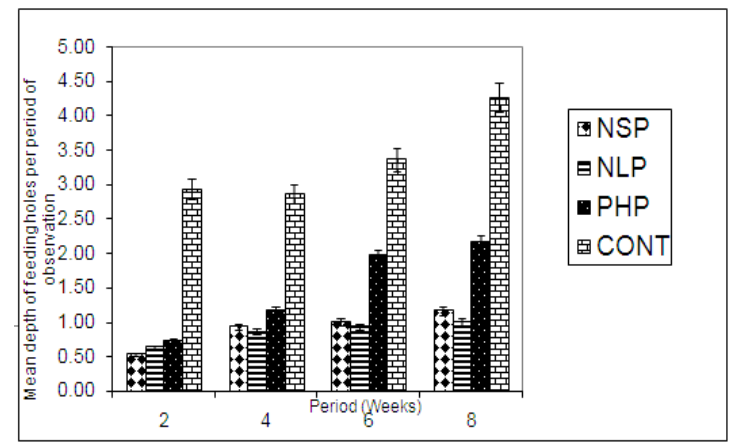

Figure 2 : Effect of Parkia husk and Neem extract on feeding holes by adult Heteroligus meles on yam tuber in Eight Weeks Of Infestation.

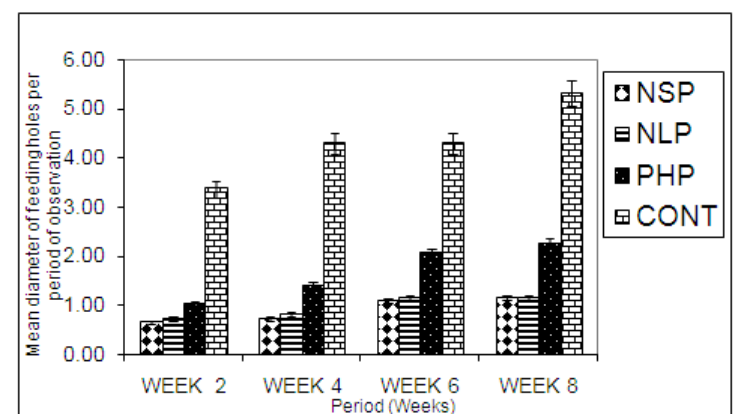

Figure 3 : Effect of Parkia husk and Neem extract on diameter of feeding holes by adult Heteroligus meles in yam tuber within eight weeks of infestation.

$\mathrm{NSP}=$ Neem seed powder, NLP $=$ Neem leaf powder, PHP $=$ Parkia husk powder, Cont $=$ Control. 
Table 1: weight $\operatorname{loss}(\%)$ of treated yam tubers infested with H. meles

\begin{tabular}{|c|c|c|c|}
\hline Treatment & & 4 wks & 8wks \\
\hline Neem seed $\quad$ ( NSP) & $3.19 b$ & $4.76 b$ & $7.94 b$ \\
\hline Neem leaf $\quad($ NLP) & $4.76 b$ & $4.76 \mathrm{~b}$ & 7.94b \\
\hline Parkia husk ( PHP) & $6.33 \mathrm{~b}$ & $9.52 b$ & $22.2 b$ \\
\hline $\mathrm{SE}+$ & 5.71 & 6.66 & 6.34 \\
\hline $\mathrm{CV} \overline{\mathrm{C}}$ & 6.44 & 7.82 & 17.2 \\
\hline
\end{tabular}

Means in a column bearing the same superscript(s) do not differ significantly $(\mathrm{P}<0.05) \quad$ SNK test. Values are means of three replicates.

\section{References}

[1]. Coursey, D. G. (1967). Yams. Longmans Green and Co. Ltd. 230pp

[2]. Emehute, J.K.U (1992). Collaborative trials on yams and other root crops, Technical reports of achievements. National Root Crops Research Institute, Umudike, Umuahia, Nigeria. In: Umeozor(1998). Evaluation of furadan as a substitute for Aldrin in the control of yam tuber beetles (H. meles) and H. appius. Nigerian Journal of Entomology 15: 100 - 106.

[3]. FAO (2008) F AO STAT. Statistical Division of the food and Agriculture organization of the United Nations, Rome, Italy, www.faostat.org.june,2008.

[4]. Gopinathan, M. C. (2007). Neem Chemical Opportunities and Challenges. In: Proceedings of World Neem Conference, $21-24$ November 2007, Coimbatore India. Gopinathn, M.C. (ed.). Published by Neem Foundation, Vithal Nager, Juhu Scheme, Mumbai, India. 2007, pg $21-33$.

[5]. Hahn, S. K., Osiru, D. S. O, Akoroda, M. O, Otoo, J. A. (1987) Yam production and its future prospects.Outlook on Agriculture 16:105-110.

[6]. Morse, S. Acholo, M. McNamara, N. and Oliver, R. (2000) Control of storage insects as means of limiting yam tuber fungal rots. Journal of Store Product Research 36: 37-45.

[7]. Okoroafor, E., Amatobi, C.I, Misari, S.M and I. Onu (2009). Field assessment of yam beetle (Heteroligus meles) damage on yam cultivars (Dioscorea spp.). Journal of Research on crops 10 (2): 398-401. http://www.cropresearch.org.

[8]. Okoroafor,E.,Misari,S.M and Onu,I (2010).Potency of Parkia Biglobosa (jacq) Husk and Azadirachta Indica (A) Juss Leaf and Seed powder in management of yam beetle, Heteroligus meles Billberger (Coleoptera: Dynastidae) on Yam (Dioscorea rotundata Poir). Nigerian Journal of Plant Protection. Vol. 24 : 119 - 129

[9]. Sabiiti, E.N. and Cobbina, J. (1992) Initial agronomic evaluation of Parkia biglobosa in humid zone of Nigeria. Agroforestry systems. 17:271-279.

[10]. SAS 2000. SAS/STAT User's Guide version 8(2). Statistical Analytical Systems Institute Inc., Cary, North Carolina, USA.

[11]. Taylor, T.A. (1964). Studies on the Nigeria yam beetles: Bionomics and control. Journal of West African Science Association 9(1):13-31.

[12]. Taylor, T.A. (1967). Insecticide residues in yam treated against yam beetles (Heteroligus spp.) infestation in Nigeria. Journal of West African Science Association 13: 139- 145.

[13]. Thacker, J.R.M. (2002). An Introduction to arthropod Pest Control. Cambridge University Press. 343pp.

[14]. Tobih, F.O., Emosairue, S.O. and Okonmah, L.U. (2007a). Studies on the occurrence and damage by yam tuber beetles (Heteroligus spp.) in Aniocha and Oshimili Areas of Delta State, Nigeria. Journal of Central European Agriculture 8(1): 129 - 134.

[15]. Tobih, F.O., Emosairue, S.O. and Omoloye, A.A. (2007 b). Evaluation of Carbofuran,

[16]. Chlorpyriphos and Endosulfan for the control of yam beetles, Heteroligus spp. (Coleoptera:

[17]. Dynastidae) in Delta State, Nigeria. Nigerian Journal of Entomology 24: $76-81$.

[18]. Umeozor (1998). Evaluation of furadan as a substitute for aldrin in the control of yam tuber

[19]. beetles (H. meles) and H. appius. Nigerian Journal of entomology 15:100-106

[20]. Taylor (1967). Insecticide residues in yam treated against yam beetles (Heteroligus spp.) infestation in Nigeria. Journal of West African Science Association 13: 139-145.

[21]. Umeozor (1998). Evaluation of furadan as a substitute for aldrin in the control of yam tuber beetles (H. meles) and H. appius. Nigerian Journal of entomology 15:100-106 